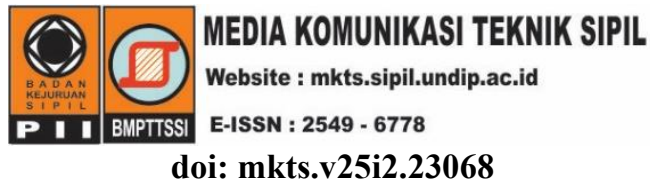

\title{
Analisa Kekuatan Tahanan Lateral Pada Sistem Komposit LVL Kayu Sengon dan Beton Pracetak
}

\author{
Intan Archita Tantisaputri, *Ali Awaludin, Suprapto Siswosukarto \\ Fakultas Teknik, Universitas Gadjah Mada, Yogyakarta \\ *)ali.awaludin@ugm.ac.id
}

Received: 10 Mei 2019 Revised: 20 Agustus 2019 Accepted: 5 September 2019

\begin{abstract}
LVL Sengon and concrete can be used to form a composite structure of the floor system. Connections between LVL Sengon and concrete on this composite floor system are the weakest part so that a majority of structural damages are concentrated at these joints. This study discusses the lateral resistance of lag screw joints in a composite system of LVL Sengon and precast concrete. The lateral joint resistance was evaluated through quasi-static loading upon double shear test specimens having two screws at every single shear. Variation of the specimens includes precast concrete compressive strength of $20.71 \mathrm{MPa}$ and $25.29 \mathrm{MPa}$, screw diameter of $6 \mathrm{~mm}$ length $101.6 \mathrm{~mm}$ and $8 \mathrm{~mm}$ length $101.6 \mathrm{~mm}$ and $127 \mathrm{~mm}$, and angle of lag screw axis against the wood fiber of $60^{\circ}$ and $90^{\circ}$. The result shows that lateral resistance of the test is greater than that of EYM, SNI, and EC5 predictions. Joint failure in this experiment is due to failure in wood fiber along with the occurrence of one up to two plastic hinges in the screw.
\end{abstract}

Keywords: Lateral resistance, shear test, composite structure, LVL sengon, precast concrete

\begin{abstract}
Abstrak
LVL kayu Sengon dan beton dapat membentuk struktur komposit sistem lantai. Sambungan antara LVL kayu Sengon dan beton pada struktur komposit sistem lantai merupakan bagian terlemah sehingga banyak kerusakan struktur akibat gagalnya sambungan. Oleh karena itu, penelitian ini membahas tentang tahanan lateral sambungan lag screw pada sistem komposit LVL kayu Sengon dan beton pracetak. Untuk mengetahui kekuatan tahanan lateral dilakukan pengujian geser sambungan dengan pembebanan statik. Benda uji dibuat dalam bentuk dua bidang geser dengan 2 sekrup pada masing-masing bidang geser. Variasi benda uji berdasarkan mutu beton pracetak 20,71 MPa dan 25,29 MPa, diameter sekrup 6 mm panjang 101,6 mm dan $8 \mathrm{~mm}$ panjang 101,6 mm dan $127 \mathrm{~mm}$, dan sudut pemasangan sekrup terhadap serat kayu $60^{\circ}$ dan $90^{\circ}$. Pada penelitian ini dilakukan pula perhitungan tahanan lateral dan kekakuan alat sambung secara teoritis. Hasil penelitian menunjukkan bahwa tahanan lateral eksperimen lebih besar bila dibandingkan dengan teori EYM, SNI dan EC5. Kegagalan sambungan pada penelitian ini berupa rusak pada kayu dan terjadi satu hingga dua sendi plastis pada alat sambung sekrup.
\end{abstract}

Kata kunci: Tahanan lateral, uji geser, struktur komposit, LVL sengon, beton pracetak

\section{Pendahuluan}

Penggunan kayu sebagai bahan konstruksi telah lama berkembang sebelum munculnya teknologi beton dan baja. Saat ini ketersediaan kayu dalam ukuran besar dengan kekuatan yang diinginkan sudah sangat terbatas (Pratiwi \& Tjondro, 2018). Sehingga Laminated Veneer Lumber (LVL) menjadi salah satu teknologi dalam mengoptimalkan penggunaan kayu. LVL dibuat dengan menggabungkan beberapa lapis kayu yang relatif tipis dengan perekat. Pada kayu utuh, cacat alami kayu sangat mempengaruhi sifat mekanik kayu. Namun, pada kayu LVL, cacat alami kayu dapat didistribusikan secara merata diantara lapisan veneer untuk meminimalkan pengaruh cacat tersebut terhadap kekuatan LVL (Eratodi \& Awaludin, 2017). Selain itu, teknologi LVL dapat meningkatkan properti mekanik kayu yang rendah, salah satunya apabila diterapkan pada kayu Sengon. Awaludin (2012) mengemukakan bahwa LVL kayu Sengon memiliki berat jenis sebesar 0,26 dan 
kelembaban sebesar 12,8\%. Selain itu, Awaludin et al. (2018) membuktikan bahwa teknologi LVL pada kayu Sengon dapat meningkatkan nilai tekan sejajar serat sebesar $53 \%$ dan nilai tekan tegak lurus serat sebesar 92\% dari nilai tekan kayu Sengon utuh.

LVL kayu Sengon dapat dimanfaatkan sebagai alternatif pengganti kayu solid yang dapat diproduksi dalam berbagai ukuran dan bentuk. Selain itu, LVL kayu Sengon juga dapat dikompositkan dengan material beton untuk membentuk struktur komposit sistem lantai. Sistem lantai komposit ini menggabungkan kekuatan tekan dan kekakuan yang dimiliki beton dengan kekuatan tarik dari kayu (Dias \& Jorge, 2011) dimana slab beton berada pada bagian atas sistem ini dan balok kayu berada pada bagian bawah yang kemudian dihubungkan dengan alat sambung mekanik. Kekuatan tarik dari kayu dapat mengurangi kemungkinan keretakan yang terjadi pada beton serta mengurangi kebutuhan baja tulangan pada beton (Yeoh et al. 2013).

Oleh karena itu, struktur lantai komposit kayubeton ini memiliki lebih banyak keunggulan bila dibandingkan dengan lantai beton bertulang saja. Fragiacomo \& Lukaszewska (2013) menyatakan bahwa pada struktur komposit sistem lantai ini, slab beton dapat mengurangi defleksi beban hidup serta kerentanan terhadap getaran sistem lantai. Selain itu slab beton juga lebih tahan terhadap api (Yeoh et al. 2010). Penggunaan struktur komposit sistem lantai kayu dan beton ini memiliki berat struktur yang lebih ringan bila dibandingkan dengan lantai beton bertulang, sehingga beban mati yang didistribusikan ke fondasi menjadi lebih sedikit.

Pada struktur komposit sistem lantai, sambungan merupakan bagian terlemah sehingga banyak kerusakan struktur akibat gagalnya sambungan. Alat sambung dapat meneruskan gaya geser serta mencegah atau mengurangi gerakan antara kayu dengan slab beton. Oleh karena itu, performa mekanik kayu dan beton sangat dipengaruhi oleh kualitas alat sambung antara kayu dan beton. Alat sambung juga harus terdeformasi secara plastis sebelum terjadi kerusakan pada bagian kayu ataupun beton (Auclair et al. 2016).

Untuk menghindari gagalnya sistem sambungan pada struktur komposit sistem lantai LVL kayu Sengon dengan beton, dilakukan penelitian mengenai sistem sambungan pada komposit LVL kayu Sengon dengan beton tersebut. Selain itu, perhitungan kapasitas tahanan lateral dan perilaku sambungan perlu diperhatikan lebih dalam.

Persamaan untuk menghitung tahanan lateral sambungan pada konstruksi kayu diusulkan oleh
Johansen (1949) yaitu Yield Model atau yang lebih dikenal dengan European Yield Model (EYM) dalam Dasar-dasar Perencanaan Sambungan Kayu (Awaludin, 2005).

Dalam teori EYM ini, kayu dan alat sambung diasumsikan berperilaku rigid-plastic. Tahanan lateral sambungan pada teori ini diperoleh apabila kekuatan tumpu ultimit kayu di bawah alat sambung tercapai, atau terbentuknya suatu atau beberapa sendi plastis pada alat sambung disertai dengan tegangan plastis pada kayu. Tahanan lateral acuan satu paku (Z) pada sambungan dengan satu irisan yang menyambung dua komponen menurut EYM dapat dilihat pada Persamaan 1 sampai dengan 4.

$$
\begin{aligned}
& I_{s}=\frac{3,3 D t_{s} F_{e s}}{K_{D}} \\
& I I I_{m}=\frac{3,3 k_{1} D p F_{e m}}{K_{D}\left(1+2 R_{e}\right)} \\
& I I I_{s}=\frac{3,3 k_{2} D t_{s} F_{e s}}{K_{D}\left(2+R_{e}\right)} \\
& I V=\frac{3,3 D^{2}}{K_{D}} \sqrt{\frac{2 F_{e m} F_{y b}}{3\left(1+R_{e}\right)}}
\end{aligned}
$$

Dengan nilai $k_{1}$ dan $k_{2}$ seperti pada Persamaan 5 dan 6 .

$$
\begin{aligned}
& k_{1}=(-1)+\sqrt{2\left(1+R_{e}\right)+\frac{2 F_{y b}\left(1+2 R_{e}\right) D^{2}}{3 F_{e m} p^{2}}} \\
& k_{2}=(-1)+\sqrt{\frac{2\left(1+R_{e}\right)}{R_{e}}+\frac{2 F_{y b}\left(1+2 R_{e}\right) D^{2}}{3 F_{e m} t_{s}^{2}}}
\end{aligned}
$$

Dimana $t_{m}$ adalah tebal kayu utama, $t_{s}$ adalah tebal kayu samping, $D$ adalah diameter alat sambung, dan $p$ adalah kedalaman penetrasi efektif batang alat pengencang pada komponen pemegang. $K_{D}$ bernilai 2,2 untuk alat sambung berdiameter kurang dari 4,3 mm, untuk alat sambung berdiameter antara 4,3 mm hingga $6,4 \mathrm{~mm}$ menggunakan nilai $K_{D}$ sebesar 0,28D+0,56 dan $K_{D}$ bernilai 3,0 untuk alat sambung berdiameter lebih dari 6,4 mm. $F_{\text {em }}$ merupakan kuat tumpu kayu utama, $F_{\text {es }}$ merupakan kuat tumpu kayu samping, dan $F_{y b}$ merupakan kuat lentur alat sambung. $R_{e}$ merupakan perbandingan antara $F_{e m}$ dan $F_{e s}$.

Terdapat enam macam moda kegagalan yang dapat terjadi pada sambungan kayu satu bidang geser. Pertama moda $I_{m}$ yang kegagalannyahanya terjadi pada kayu utama, pada kegagalan ini dapat satu atau dua bidang geser. Kedua, moda $I_{s}$ dimana kegagalan 
ini terjadi pada kayu samping dan bidang geser yang terjadi bisa satu maupun dua bidang geser. Ketiga, moda II dengan kegagalan yang terjadi ada pada kayu utama dan kayu samping, sehingga tipe sambungannya memiliki satu bidang geser. Keempat, moda $I I I_{m}$ dimana kayu utama mengalami kerusakan dan alat sambung yang terletak pada kayu samping mulai gagal, moda ini memiliki satu bidang geser.

Kelima, moda $I I I_{s}$ memiliki satu maupun dua bidang geser akibat kerusakan terjadi pada kayu samping dan alat sambung yang terletak pada kayu utama mulai gagal. Serta moda $I V$ dimana alat sambung yang terletak pada kayu utama dan kayu samping mengalami kegagalan. Pada moda $I V$ terdapat satu atau dua bidang geser. Ilustrasi moda kegagalan dapat dilihat pada Gambar 1.

Selain teori EYM, Standar Nasional Indonesia (SNI) 7973:2013 dan BS EN 1995 1-1: Eurocode 5 (2004) juga memiliki persamaan untuk menghitung tahanan lateral acuan satu paku $(\mathrm{Z})$ pada sambungan dengan satu irisan yang menyambung dua komponen. Persamaan SNI 7973 (2013) untuk menghitung nilai $\mathrm{Z}$ seperti pada Persamaan 7 hingga 12 .

$$
\begin{aligned}
& I_{m}=\frac{D l_{m} F_{e m}}{R_{d}} \\
& I_{s}=\frac{D l_{s} F_{e s}}{R_{d}} \\
& I I=\frac{k_{1} D l_{s} F_{e s}}{R_{d}} \\
& I I I_{m}=\frac{k_{2} D l_{m} F_{e m}}{\left(1+2 R_{e}\right) R_{d}} \\
& I I I_{s}=\frac{k_{3} D l_{s} F_{e s}}{\left(2+R_{e}\right) R_{d}} \\
& I V=\frac{D^{2}}{R_{d}} \sqrt{\frac{2 F_{e m} F_{y b}}{3\left(1+R_{e}\right)}}
\end{aligned}
$$

Dengan nilai $k_{1}, k_{2}$, dan $k_{3}$ seperti pada Persamaan 13 hingga 15.

$$
\begin{aligned}
& k_{1}=\frac{\sqrt{R_{e}+2 R_{e}^{2}\left(1+R_{t}+R_{t}^{2}\right)+R_{t}^{2} R_{e}^{3}}-R_{e}\left(1+R_{t}\right)}{\left(1+R_{e}\right)} \\
& k_{2}=-1+\sqrt{2\left(1+R_{e}\right)+\frac{2 F_{y b}\left(1+2 R_{e}\right) D^{2}}{3 F_{e m} l_{m}{ }^{2}}}
\end{aligned}
$$

$$
k_{3}=-1+\sqrt{\frac{2\left(1+R_{e}\right)}{R_{e}}+\frac{2 F_{y b}\left(2+R_{e}\right) D^{2}}{3 F_{e m} l_{s}^{2}}}
$$

Pada Persamaan 7 hingga $12, l_{m}$ adalah panjang tumpu pada kayu utama, $l_{s}$ adalah panjang tumpu pada kayu samping, $R_{d}$ adalah faktor reduksi, dan $R_{t}$ adalah perbandingan antara $l_{m}$ dengan $l_{s}$.
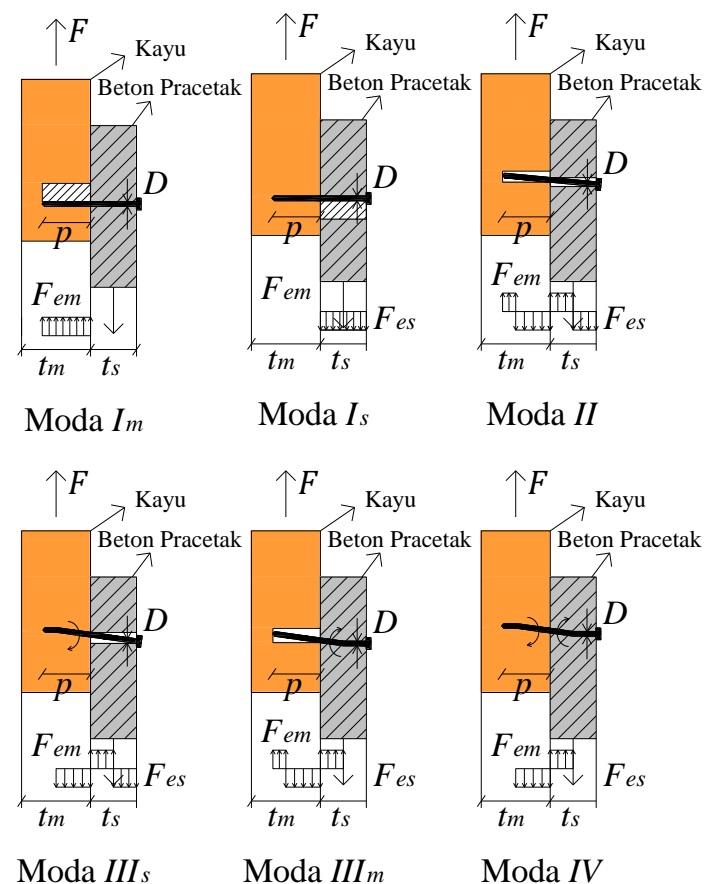

\section{Gambar 1. Moda kegagalan sambungan dengan satu bidang geser}

Sambungan dengan pemasangan sekrup miring memiliki perilaku yang lebih kompleks akibat adanya kombinasi gaya lateral dan gaya cabut dari sekrup tersebut (Girhammar et al. 2017).

Dalam BS EN 1995 1-1: Eurocode 5 (2004), persamaan untuk menghitung nilai tahanan lateral (Z) telah memasukkan parameter nilai cabut sekrup dalam perhitungannya. Persamaan BS EN 1995 11: Eurocode 5 (2004) untuk menghitung nilai $\mathrm{Z}$ seperti pada Persamaan 16 hingga Persamaan 21.

$$
\begin{aligned}
& I_{s}=f_{h, 1, k} \cdot t_{1} \cdot D \\
& I_{m}=f_{h, 2, k} \cdot t_{2} \cdot D
\end{aligned}
$$

$$
\begin{aligned}
& I I=\frac{f_{h, 1, k} \cdot t_{1} \cdot D}{1+\beta}\left[\sqrt{\beta+2 \beta^{2}\left[1+\frac{t_{2}}{t_{1}}+\left(\frac{t_{2}}{t_{1}}\right)^{2}\right]+\beta^{3}\left(\frac{t_{2}}{t_{1}}\right)^{2}}-\right. \\
& \left.\beta\left(1+\frac{t_{2}}{t_{1}}\right)\right]+\frac{F_{a x, R k}}{4}
\end{aligned}
$$




$$
\begin{aligned}
I I I_{s} & =1,05 \frac{f_{h, 1, k} \cdot t_{1} \cdot D}{2+\beta}\left[\sqrt{2 \beta(1+\beta)+\frac{4 \beta(2+\beta) M_{y, R k}}{f_{h, 1, k} \cdot t_{1}^{2} \cdot D}}-\beta\right] \\
& +\frac{F_{a c, R k}}{4} \\
I I I_{m} & =1,05 \frac{f_{h, 1, k} \cdot t_{2} \cdot D}{1+2 \beta}\left[\sqrt{2 \beta^{2}(1+\beta)+\frac{4 \beta(1+2 \beta) M_{y, R k}}{f_{h, 1, k} \cdot t_{2}^{2} \cdot D}}-\beta\right] \\
+ & \frac{F_{a c, R k}}{4} \\
I V & =1,15 \sqrt{\frac{2 \beta}{1+\beta}} \sqrt{2 M_{y, R k} \cdot f_{h, 1, k} \cdot D}+\frac{F_{a x, R k}}{4}
\end{aligned}
$$

Dimana $t_{1}$ adalah tebal kayu samping, $t_{2}$ adalah tebal kayu utama, $D$ adalah diameter alat sambung, $f_{h, l, k}$ merupakan kuat tumpu kayu samping, $f_{h, 2, k}$ merupakan kuat tumpu kayu utama, $\beta$ merupakan perbandingan antara $f_{h, 2, k}$ dan $f_{h, l, k}, M_{y, R k}$ adalah momen elastis dan $F_{a x, R k}$ adalah kuat cabut dari alat sambung.

Penggunaan alat sambung yang kuat dan kaku sangat diperlukan untuk menahan gaya geser pada sistem komposit (Yeoh et al. 2011). Kekakuan merupakan ketahanan bahan terhadap deformasi yang terjadi. Bahan mampu meregang pada tegangan tinggi tanpa diikuti dengan regangan yang besar. Tingkat kekakuan suatu bahan ditunjukkan oleh sudut yang dibentuk oleh tegangan dan regangan pada daerah elastik. Perhitungan nilai kekakuan pada penelitian ini mengacu pada ISO 6891:1983 (1983). Persamaan untuk menghitung nilai kekakuan $\left(k_{s}\right)$ dapat dilihat seperti pada Persamaan 22:

$k_{s}=0,4 \frac{F_{\max }}{v_{i}}$

Dimana $F_{\max }$ merupakan beban maksimum dan $v_{i}$ adalah selip pada saat beban $40 \%$.

Penelitian mengenai alat sambung pada struktur komposit kayu dan beton telah banyak diteliti. Suriani (2012) meninjau kekuatan lateral pada sambungan komposit kayu dan beton menggunakan alat sambung sekrup kunci, tahanan lateral yang diperoleh dari pengujian eksperimen lebih tinggi bila dibandingkan dengan prediksi perhitungan secara teoritis. Studi perilaku geser pada struktur komposit beton-kayu dengan alat sambung baut pernah diteliti oleh He, et al. (2016), kapasitas geser dan modulus geser pada alat sambung baut berbanding lurus dengan diameter baut. Khorsandnia, et al. (2012) dalam penelitiannya menyatakan bahwa tidak ada keretakan atau kerusakan yang terjadi pada beton yang dikompositkan dengan kayu, karena alat sambung tidak cukup kuat untuk menyebabkan kerusakan pada beton. Penelitian yang dilakukan Symons et al. (2010) menunjukkan bahwa kekuatan dan kekakuan alat sambung pada komposit kayu dan beton akan semakin meningkat apabila alat sambung sekrup dipasang miring ke arah gesernya.

Pada penelitian ini alat sambung mekanik yang akan digunakan adalah alat sambung sekrup jenis lag screw dan beton yang digunakan adalah beton pracetak dengan perkuatan wiremesh. Hasil akhir yang diharapkan dalam penelitian ini adalah untuk mengetahui perilaku moda kegagalan sambungan dan memperoleh nilai kekuatan tahanan lateral dari sistem komposit LVL kayu Sengon dan beton pracetak menggunakan alat sambung mekanik lag screw dengan beberapa variasi dimensi sekrup dan sudut pemasangan alat sambung.

\section{Metode}

Penelitian ini berfokus pada kapasitas geser alat sambung sistem komposit LVL kayu Sengon dengan beton pracetak yang dibebani secara statik. Benda uji penelitian berupa LVL kayu Sengon berukuran tinggi $400 \mathrm{~mm}$, lebar $80 \mathrm{~mm}$, dan tebal $50 \mathrm{~mm}$ dan beton pracetak dengan tulangan wiremesh berukuran tinggi $400 \mathrm{~mm}$, lebar $150 \mathrm{~mm}$, dan tebal $50 \mathrm{~mm}$ yang disambung dengan alat sambung mekanik berupa sekrup jenis lag screw. Dimana lag screw pada teori EYM termasuk kedalam jenis dowel-type fasteners. Pada penelitian ini, kehadiran ulir pada lag screw diabaikan sehingga teori EYM, SNI dan EC5 dapat digunakan untuk menentukan tahanan lateral alat sambung.

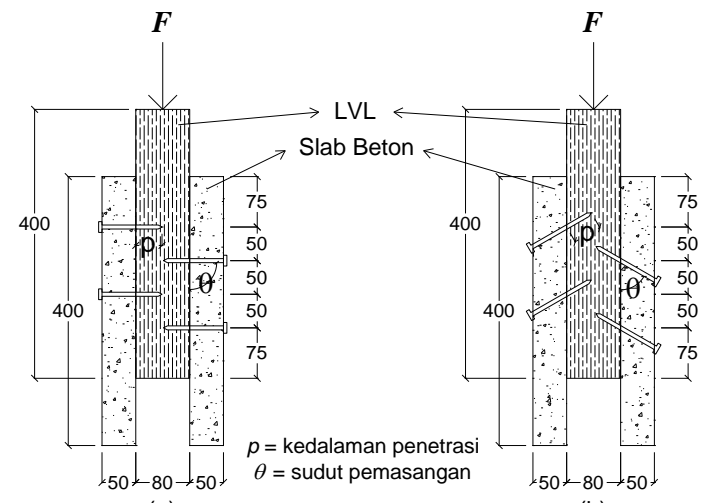

(a)

(b)

Gambar 2. (a) Sketsa benda uji sudut pemasangan $90^{\circ}$; (b) Sketsa benda uji sudut pemasangan $60^{\circ}$

Benda uji pada penelitian ini menggunakan model benda uji double shear. Model ini dipilih karena memberi kemudahkan dalam pelaksanaan pengujian mengingat benda uji dengan model 
single-shear berpotensi memberikan gaya tekan dari mesin hydraulic yang tidak sentris. Sketsa benda uji dengan sudut pemasangan $90^{\circ}$ dapat dilihat pada Gambar 2 (a), Gambar 2 (b) merupakan sketsa benda uji dengan sudut pemasangan $60^{\circ}$ dan dokumentasi benda uji asli dapat dilihat pada Gambar 3.

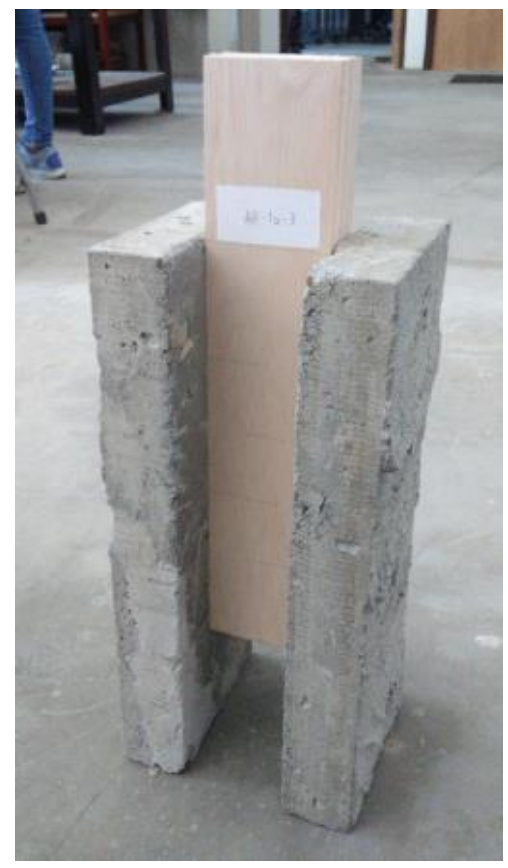

Gambar 3. Dokumentasi benda uji

Benda uji divariasikan berdasarkan mutu beton pracetak $\left(f c^{\prime}\right)$, diameter sekrup $(D)$, kedalaman penetrasi $(p)$, dan sudut pemasangan $\operatorname{sekrup}(\theta)$, dengan jumlah masing-masing sampel tersaji pada Tabel 1, dimana $P$ adalah panjang sekrup dan $n$ adalah jumlah benda uji.

Tabel 1. Spesifikasi benda uji.

\begin{tabular}{lcccccc}
\hline Kode & $\begin{array}{c}\boldsymbol{f} \boldsymbol{c}^{\boldsymbol{}} \\
(\mathbf{M P a})\end{array}$ & $\begin{array}{c}\boldsymbol{D} \\
(\mathbf{m m})\end{array}$ & $\begin{array}{c}\boldsymbol{\theta} \\
\left(^{\circ}\right)\end{array}$ & $\begin{array}{c}\boldsymbol{P} \\
(\mathbf{m m})\end{array}$ & $\begin{array}{c}\boldsymbol{p} \\
(\mathbf{m m})\end{array}$ & $\mathbf{N}$ \\
\hline $\mathrm{A} 8-1 \mathrm{x}$ & 20,71 & 8 & 90 & 101,6 & 51,6 & 3 \\
$\mathrm{~B} 6-1 \mathrm{x}$ & 25,29 & 6 & 90 & 101,6 & 51,6 & 5 \\
$\mathrm{~B} 6-2 \mathrm{x}$ & 25,29 & 6 & 60 & 101,6 & 42,1 & 2 \\
$\mathrm{~B} 8-1 \mathrm{x}$ & 25,29 & 8 & 90 & 101,6 & 51,6 & 5 \\
$\mathrm{~B} 8-1 \mathrm{y}$ & 25,29 & 8 & 90 & 127,0 & 77,0 & 4 \\
$\mathrm{~B} 8-2 \mathrm{y}$ & 25,29 & 8 & 60 & 127,0 & 66,9 & 5 \\
\hline
\end{tabular}

Keterangan notasi:

- Simbol A dan B untuk mutu beton,

$A=f_{c}^{\prime} 20,71 \mathrm{MPa}$ dan $B=f_{c}^{\prime} 25,29 \mathrm{Mpa}$

- Simbol 6 dan 8 untuk diameter sekrup

- Simbol 1 dan 2 untuk sudut pemasangan, $1=90^{\circ}$ dan $2=60^{\circ}$

- Simbol $x$ dan y untuk panjang sekrup, $x=101,6 \mathrm{~mm}$ dan $y=127 \mathrm{~mm}$

Pembuatan benda uji sambungan antara LVL kayu Sengon dengan beton pracetak dibuat dengan menambahkan alat sambung mekanik yaitu lag screw. Lag screw diletakkan pada lubang yang telah tersedia pada benda uji beton pracetak lalu dikencangkan pada LVL kayu Sengon yang telah di bor terlebih dahulu. Pengencangan sambungan hanya dilakukan hingga kepala sekrup menyentuh permukaan benda uji beton lalu diberi grouting menggunakan epoxy untuk menutup lubang pada beda uji beton.

Pembebanan pada saat pengujian dilakukan secara statik dengan mengacu standar pembebanan ISO 6891:1983 menggunakan alat universal testing machine. Benda uji beton pracetak dan LVL kayu Sengon diberi LVDT pada kedua sisi. Pada saat pengujian, LVDT dan load cell terhubung pada data logger sehingga beban dan selip yang terjadi dapat terekam. Gambar 4 merupakan skema settingup alat uji lateral secara statik yang digunakan pada penelitian ini dan Gambar 5 adalah dokumentasi proses pembebanan benda uji berlangsung.

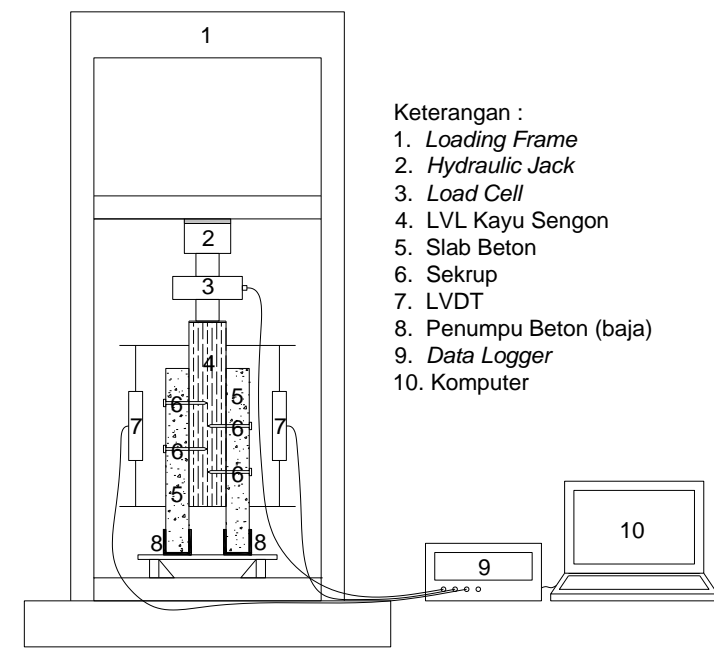

Gambar 4. Skema setting-up alat pengujian

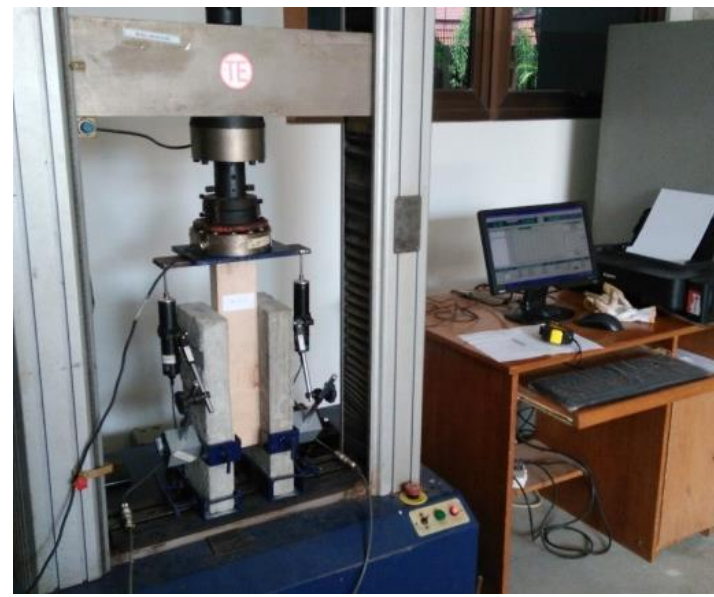

Gambar 5. Proses pembebanan

Dalam melakukan perhitungan tahanan lateral, dibutuhkan beberapa parameter masukan 
diantaranya kuat lentur lag screw, kuat tumpu dan kuat cabut lag screw pada LVL kayu Sengon. Parameter-parameter tersebut didapatkan dari hasil pengujian material di laboratorium. Untuk mendapatkan nilai kuat lentur lag screw, dilakukan uji tarik lag screw berdasarkan ASTM E8 M dengan benda uji berjumlah tiga buah lag screw diameter $8 \mathrm{~mm}$. Pengujian tumpu lag screw pada LVL kayu Sengon dilakukan sesuai dengan ASTM-D 5764 dengan lima buah benda uji berupa LVL kayu Sengon berukuran $40 \mathrm{~mm}$ x $80 \mathrm{~mm}$ x $60 \mathrm{~mm}$ diberi lubang berukuran setengah diameter lag screw pada tepi atasnya. Pada pengujian kuat cabut lag screw, pengujian dilakukan terhadap dua sudut pemasangan, yaitu $90^{\circ}$ dan $60^{\circ}$. Lag screw berdiameter $8 \mathrm{~mm}$ dan $6 \mathrm{~mm}$ ditancapkan pada LVL kayu Sengon berukuran $40 \mathrm{~mm}$ x $80 \mathrm{~mm}$ x $200 \mathrm{~mm}$ dan dilakukan pengujian cabut sesuai dengan ASTM-D 1761 dengan jumlah benda uji masingmasing sebanyak 6 buah.

\section{Hasil dan Pembahasan}

Hasil pengujian kuat lentur lag screw, kuat tumpu dan kuat cabut lag screw pada LVL kayu Sengon yang telah dilakukan, didapatkan nilai kuat lentur lag screw sebesar $568 \mathrm{MPa}$, kuat tumpu lag screw pada LVL kayu Sengon sebesar 4,12 MPa untuk lag screw diameter $8 \mathrm{~mm}$ dan 2,93 MPa untuk lag screw diameter $6 \mathrm{~mm}$. Selain itu, pada pengujian kuat cabut lag screw pada LVL kayu Sengon menggunakan lag screw berdiameter $8 \mathrm{~mm}$ didapatkan nilai kuat cabut sebesar $14,55 \mathrm{MPa}$ untuk sudut pemasangan $90^{\circ}$ dan $12,30 \mathrm{MPa}$ untuk sudut pemasangan $60^{\circ}$ serta pada penggunaan lag screw berdiameter $6 \mathrm{~mm}$ didapatkan nilai kuat cabut sebesar 12,23 $\mathrm{MPa}$ untuk sudut pemasangan $90^{\circ}$ dan $11,96 \mathrm{MPa}$ untuk sudut pemasangan $60^{\circ}$.

Hasil pengujian sambungan komposit LVL kayu Sengon dan beton pracetak tersaji dalam bentuk grafik. Nilai maksimum, minimum dan rata-rata beban yang mampu diterima tiap kelompok benda uji dua bidang geser tersaji dalam Tabel 2 .

Tabel 2. Hasil pengujian geser

\begin{tabular}{lcrrr}
\hline & $\begin{array}{c}\text { Jumlah } \\
\text { sampel } \\
\text { (buah) }\end{array}$ & $\begin{array}{c}\text { Beban } \\
\mathbf{m a x} \\
(\mathbf{k N})\end{array}$ & $\begin{array}{c}\text { Beban } \\
\mathbf{m i n} \\
\mathbf{( k N )}\end{array}$ & $\begin{array}{c}\text { Rata- } \\
\text { rata } \\
(\mathbf{k N})\end{array}$ \\
\hline $\mathrm{A} 8-1 \mathrm{x}$ & 3 & 35,60 & 17,66 & 26,58 \\
$\mathrm{~B} 6-1 \mathrm{x}$ & 5 & 18,97 & 13,79 & 15,69 \\
$\mathrm{~B} 6-2 \mathrm{x}$ & 2 & 8,47 & 8,47 & 8,47 \\
$\mathrm{~B} 8-1 \mathrm{x}$ & 5 & 18,97 & 16,29 & 17,61 \\
$\mathrm{~B} 8-1 \mathrm{y}$ & 4 & 23,79 & 18,85 & 21,49 \\
$\mathrm{~B} 8-2 \mathrm{y}$ & 5 & 15,16 & 13,22 & 14,41 \\
\hline
\end{tabular}

Benda uji dengan kode A8-1x memiliki ketahanan lateral paling tinggi, hal ini disebabkan oleh pengaruh dari penggunaan epoxy pada bagian sambungan yang sampai menyentuh permukaan LVL kayu Sengon sehingga dapat menahan beban yang lebih besar. Sedangkan pada benda uji lainnya penggunaan epoxy tidak sampai menyentuh permukaan LVL kayu Sengon. Hasil pengujian dari beberapa variasi benda uji tersebut, benda uji dengan pemasangan sekrup bersudut $60^{\circ}$ memiliki nilai tahanan lateral yang paling rendah yaitu $8,47 \mathrm{kN}$ untuk sekrup berdiameter $6 \mathrm{~mm}$ dan $14,41 \mathrm{kN}$ untuk sekrup berdiameter $8 \mathrm{~mm}$.

Data hasil pengujian diolah untuk mencari nilai kekakuan masing-masing sekrup dengan menggunakan Persamaan 22 yang mengacu pada ISO 6891:1983. Perhitungan nilai kekakuan dilakukan tiap sampel pada masing-masing kelompok benda uji kemudian dicari nilai dirataratanya. Nilai kekakuan yang diperoleh disajikan dalam Tabel 3. Secara teoritis, perhitungan tahanan lateral berdasarkan persamaan EYM, SNI dan EC5 memiliki hasil seperti yang ditampilkan pada Tabel 4. Grafik nilai kekakuan $(k)$, tahanan lateral menurut EYM dan tahanan lateral menurut SNI dengan grafik hubungan beban dengan selip satu sekrup dapat dilihat pada Gambar 6 hingga 11.

Tabel 3. Perhitungan nilai kekakuan satu sekrup

\begin{tabular}{ccccc}
\hline & $\begin{array}{c}\text { Jumlah } \\
\text { sampel } \\
\text { (buah) }\end{array}$ & $\begin{array}{c}\text { Nilai } \boldsymbol{k} \\
\text { max } \\
(\mathbf{k N / m m})\end{array}$ & $\begin{array}{c}\text { Nilai } \boldsymbol{k} \\
\text { min } \\
(\mathbf{k N} / \mathbf{m m})\end{array}$ & $\begin{array}{c}\text { Nilai } \boldsymbol{k} \\
\text { rata-rata } \\
(\mathbf{k N} / \mathbf{m m})\end{array}$ \\
\hline $\mathrm{A} 8-1 \mathrm{x}$ & 3 & 6,30 & 1,78 & 3,37 \\
$\mathrm{~B} 6-1 \mathrm{x}$ & 5 & 2,03 & 0,65 & 1,47 \\
$\mathrm{~B} 6-2 \mathrm{x}$ & 2 & 2,54 & 1,49 & 2,02 \\
$\mathrm{~B} 8-1 \mathrm{x}$ & 5 & 5,68 & 0,73 & 2,84 \\
$\mathrm{~B} 8-1 \mathrm{y}$ & 4 & 2,56 & 0,81 & 1,34 \\
$\mathrm{~B} 8-2 \mathrm{y}$ & 5 & 2,39 & 0,45 & 1,15 \\
\hline
\end{tabular}

Tabel 4. Perhitungan tahanan lateral (kN)

\begin{tabular}{ccccc}
\hline Kode & $\begin{array}{c}\text { Eksperimen } \\
\text { kN }\end{array}$ & \multicolumn{3}{c}{ Persentase (\%) } \\
\cline { 3 - 5 } & 3,15 & 60,47 & 17,04 & 53,98 \\
A8-1x & $\left(I I I_{m}\right)$ & $\left(I I I_{m}\right)$ & $\left(I_{m}\right)$ & $\left(I_{m}\right)$ \\
\hline B6-1x & 2,98 & 55,98 & 1,02 & 53,38 \\
& $\left(I I I_{m}\right)$ & $\left(I I I_{m}\right)$ & $\left(I I I_{m}\right)$ & $\left(I_{m}\right)$ \\
\hline B6-2x & 1,62 & 76,02 & 1,28 & 54,34 \\
& $\left(I I I_{m}\right)$ & $\left(I I I_{m}\right)$ & $\left(I_{m}\right)$ & $\left(I_{m}\right)$ \\
\hline B8-1x & 3,26 & 58,67 & 16,42 & 52,07 \\
& $\left(I I I_{m}\right)$ & $\left(I I I_{m}\right)$ & $\left(I_{m}\right)$ & $\left(I_{m}\right)$ \\
\hline B8-1y & 3,61 & 55,25 & 19,80 & 70,34 \\
& $\left(I I I_{m}\right)$ & $\left(I I I_{m}\right)$ & $\left(I I I_{m}\right)$ & $\left(I_{m}\right)$ \\
\hline B8-2y & 2,12 & 69,12 & 20,80 & 61,56 \\
& $\left(I I I_{m}\right)$ & $\left(I I I_{m}\right)$ & $\left(I_{m}\right)$ & $\left(I_{m}\right)$ \\
\hline
\end{tabular}

Berdasarkan perhitungan secara teori EYM, SNI dan EC5 menunjukkan nilai tahanan lateral yang lebih rendah dari hasil pengujian (Tabel 4). Dari 
ketiga teori tersebut, nilai tahanan lateral pada perhitungan teori SNI memiliki nilai yang paling rendah dan moda kegagalan yang terjadi berada pada moda kegagalan $I_{m}$ dan $I I I_{m}$, hal ini diakibatkan oleh nilai koefisien ragam kelelehan yang berbeda-beda untuk masing-masing variasi. Selain itu, pada teori EC5, kuat cabut sekrup diikut sertakan dalam perhitungan tahanan lateral moda $I I$, $I I I_{m}, I I_{s}$, dan $I V$, akibatnya moda kegagalan yang terjadi pada perhitungan tahanan lateral secara teori EC5 menunjukkan moda kegagalan $I_{m}$.

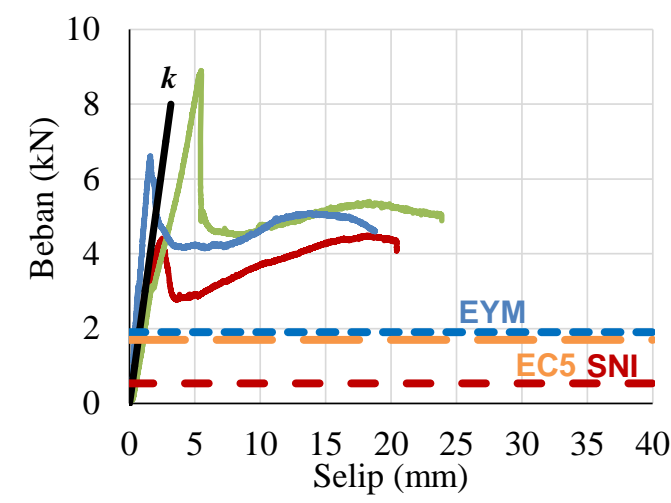

Gambar 6. Grafik hubungan beban dengan selip benda uji kode A8-1x

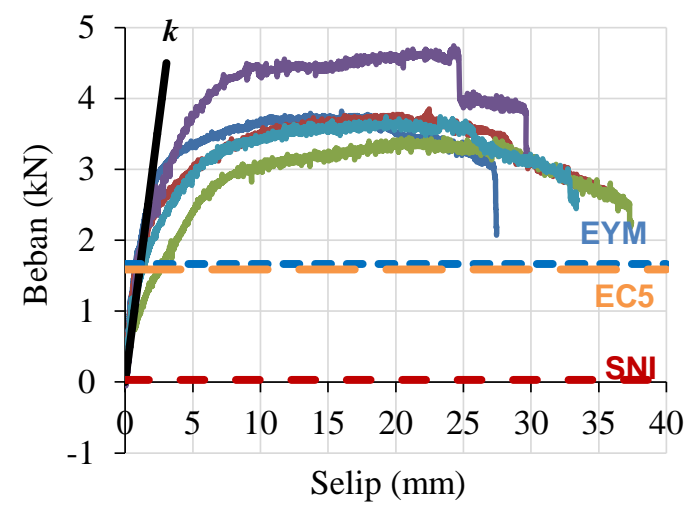

Gambar 7. Grafik hubungan beban dengan selip benda uji kode B6-1x

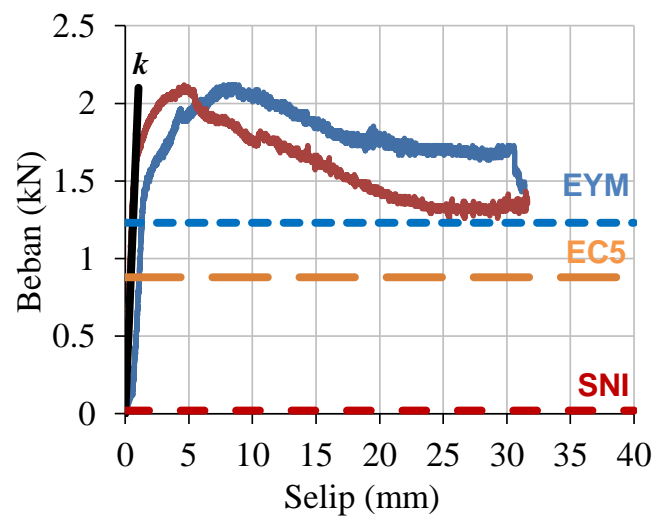

Gambar 8. Grafik hubungan beban dengan selip benda uji kode B6-2x

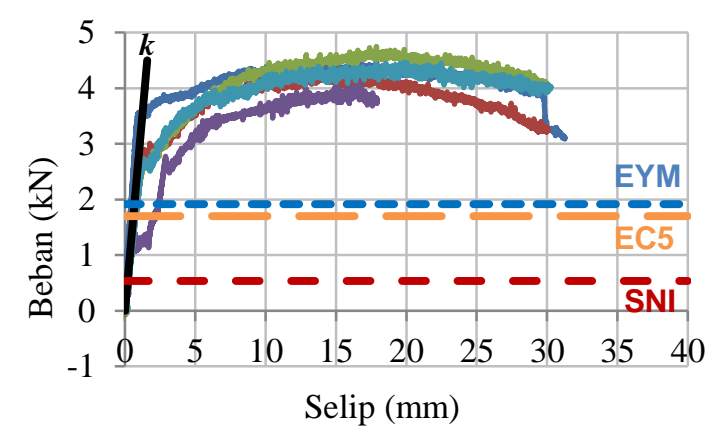

Gambar 9. Grafik hubungan beban dengan selip benda uji kode $B 8-1 x$

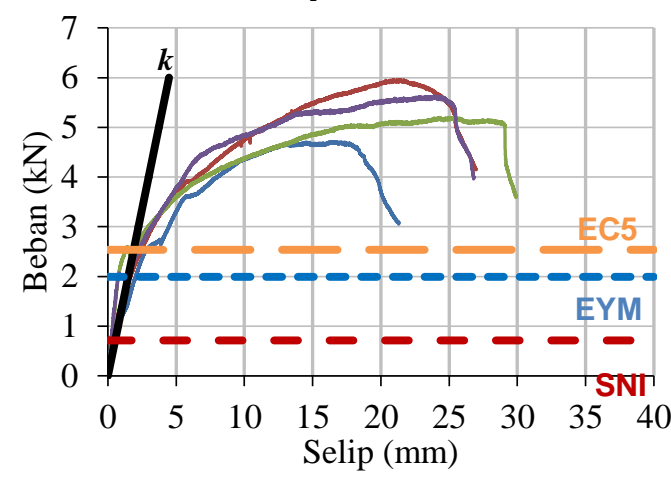

\section{Gambar 10. Grafik hubungan beban dengan selip benda uji kode B8-1y}

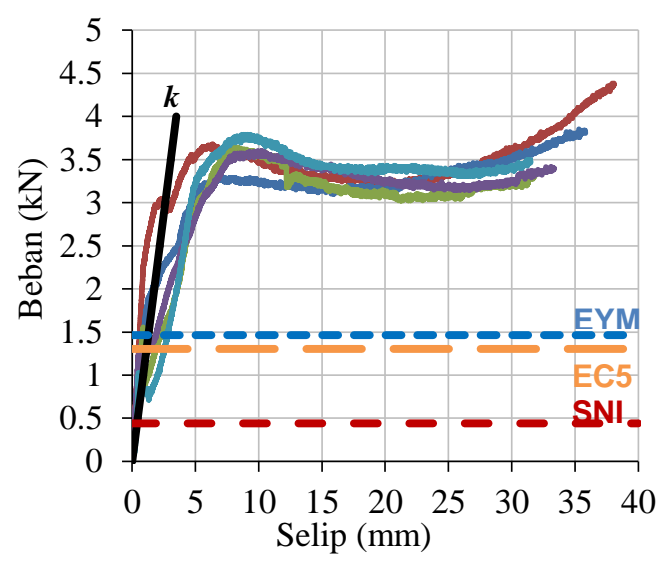

\section{Gambar 11. Grafik hubungan beban dengan selip benda uji B8-2y}

Kerusakan yang terjadi pada komponen sambungan diamati secara visual kemudian dibandingkan dengan teori moda kegagalan EYM, SNI dan EC5 untuk menentukan moda kegagalan sambungannya. Pada penelitian ini, beton tidak mengalami kegagalan diakibatkan mutu beton pracetak yang digunakan jauh melebihi dari mutu LVL kayu Sengon yaitu 20,71 dan 25,29 MPa. Moda kegagalan sambungan yang sesuai pada penelitian ini adalah moda kegagalan $I I I_{m}$, terlihat dari kerusakan yang terjadi pada kayu dan bentuk lag screw yang bengkok karena terjadi satu maupun dua sendi plastis. Kerusakan yang terjadi pada kayu dapat dlihat pada Gambar 12 (a) hingga Gambar 12 
(f) dan bentuk kegagalan lag screw dapat dilihat pada Gambar 13 (a) hingga Gambar 13 (f).

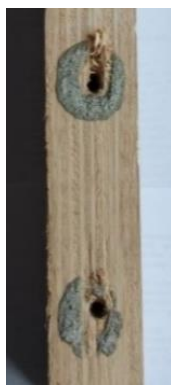

(a)

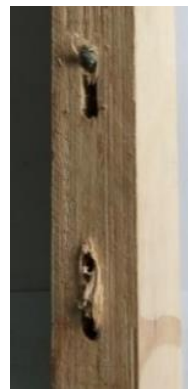

(d)

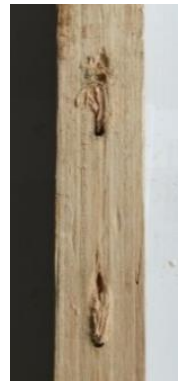

(b)

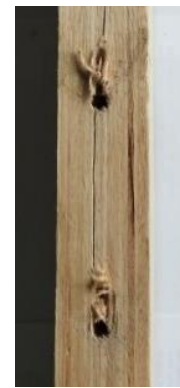

(e)

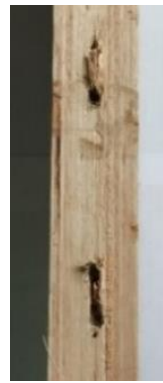

(c)

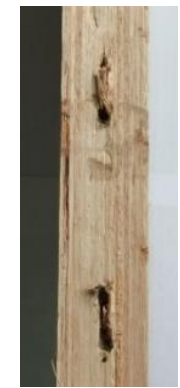

(f)
Gambar 12. Kerusakan pada kayu; (a) kode A8-1x; (b) kode B6-1x; (c) kode B6-2x; (d) kode B8-1x; (e) kode B8-1y; (f) kode B8-2y

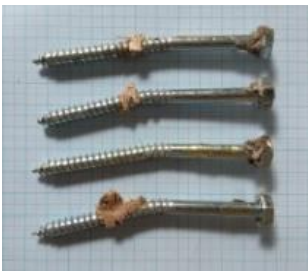

(a)

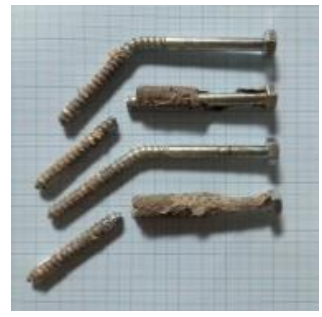

(c)

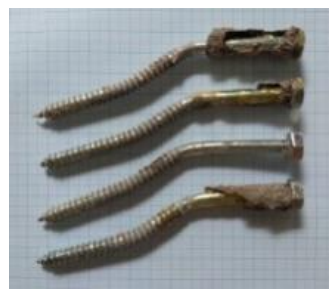

(e)

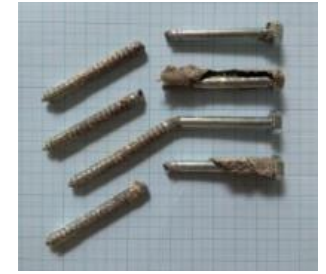

(b)

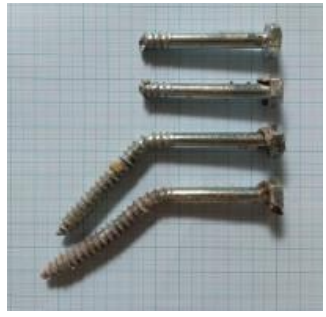

(d)

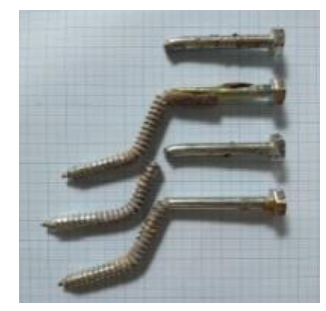

(f)
Gambar 13. Kerusakan pada sekrup; (a) kode A8-1x; (b) kode B6-1x; (c) kode B6-2x; (d) kode B8-1x; (e) kode B8-1y; (f) kode B8-2y

\section{Kesimpulan}

Berdasarkan hasil penelitian, benda uji dengan pemasangan sudut sekrup $90^{\circ}$ memiliki ketahanan lateral yang lebih baik bila dibandingkan dengan benda uji dengan pemasangan sudut sekrup $60^{\circ}$. Selain itu, semakin besar dimensi alat sambung sekrup yang digunakan pada penelitian ini juga menghasilkan nilai tahanan lateral yang lebih besar, terbukti dengan benda uji B8-1x yang menggunakan sekrup berdiameter $8 \mathrm{~mm}$ dengan panjang sekrup $127 \mathrm{~mm}$ mampu menahan beban sebesar $21,49 \mathrm{kN}$.

Berdasarkan perhitungan tahanan lateral secara teoritis, persentase tahanan lateral hasil perhitungan dengan persamaan EYM, SNI dan EC5 menunjukkan nilai yang lebih rendah bila dibandingkan dengan hasil pengujian. Secara visual, moda kegagalan yang terjadi pada penelitian ini adalah moda kegagalan $I I I_{m}$, dimana kerusakan terjadi pada kayu dan alat sambung mekanik lag screw.

Pada penelitian selanjutnya diharapkan lebih memperhatikan penggunaan epoxy agar hasil tahanan lateral alat sambung murni akibat kegagalan komponen kayu, beton maupun kegagalan alat sambung itu sendiri.

\section{Ucapan Terima Kasih}

Penulis mengucapkan terimakasih atas dukungan finansial kepada Direktorat Jendral Penguatan Riset dan Pengembangan Kementrian Riset, Teknologi dan Pendidikan Tinggi melalui program Penelitian Terapan Unggulan Perguruan Tinggi 2018, PT. Sumber Graha Sejahtera, dan pihak PT. Aneka Dharma Persada, Sedayu, Bantul, Yogyakarta.

\section{Daftar Pustaka}

ASTM (2000). ASTM-D 1761: Standard methods of testing mechanical fastener in wood, nail, staple or screw withdrawal test. ASTM International, West Conshohocken, PA.

ASTM (2009). ASTM E8 M: Standard test methods for tension testing of metalic materials. ASTM International, West Conshohocken, PA.

ASTM (2018). ASTM-D 5764: Standard test methods for evaluating dowel-bearing strength of wood and wood-based products. ASTM International, West Conshohocken, PA.

Auclair, S. C., Sorelli, L., \& Salenikovich, A. (2016). A New Composite Connector for Timber- 
Concrete Composite Structures. Construction and Building Materials, 112, 84-92.

Awaludin, A. (2005). Dasar-dasar perencanaan sambungan kayu (Edisi 1.). Yogyakarta: Biro Penerbit KMTS JTSL FT UGM., Yogyakarta.

Awaludin, A (2012). Development of Structural Walls Made from LVL Sengon (Paraserianthes falcataria): Basic Mechanical Properties, dipresenasikan pada International Conference on Sustainable Civil Engineering Structures and Construction Materials (SCESCM), Yogyakarta, Indonesia: Departemen Teknik Sipil dan Lingkungan, Universitas Gadjah Mada, 299-302.

Awaludin, A., Shahidan, S., Basuki, A., Zuki, S. S. M., \& Nazri, F. M. (2018). Laminated Veneer Lumber (LVL) Sengon: an Innovative Sustainable Building Material in Indonesia. International Journal of Integrated Engineering, 10(1), 17-22.

BS EN 1995 1-1, (2004). Eurocode 5: Design of Timber Structures - Part 1-1: General - Common Rules and Rules for Buildings, British Standards Institution, London, UK

Dias, A. M., \& Jorge, L. F. (2011). The Effect of Ductile Connectors on the Behaviour of TimberConcrete Composite Beams. Engineering structures, 33(11), 3033-3042.

Eratodi, I. B., \& Awaludin, A. (2017). Bending Capacity of Non-prismatic LVL Beams Paraserianthes Falcataria, dipresentasikan pada Procedia Engineering, 171, 1362-1369.

Fragiacomo, M., \& Lukaszewska, E. (2013). TimeDependent Behavior of Timber-Concrete Composite Floors with Prefabricated Concrete Slabs. Engineering Structures, 52, 687-696.

Girhammar, U. A., Jacquier, N., \& Källsner, B. (2017). Stiffness Model for Inclined Screws in Shear-Tension Mode in Timber-To-Timber Joints. Engineering structures, 136, 580-595.

He, G., Xie, L., Wang, X. A., Yi, J., Peng, L., Chen, Z. A., ... \& Crocetti, R. (2016). Shear Behavior Study on Timber-Concrete Composite Structures with Bolts. Bio Resources, 11(4), 9205-9218.
International Organization for Standardization, (1983). ISO 6891:1983 Timber structures: joints made with mechanical fasteners- general principles for the determination of strength and deformation characteristics (first ed.), Canada.

Khorsandnia, N., Valipour, H. R., \& Crews, K. (2012). Experimental and Analytical Investigation of Short-Term Behavior of LVL-Concrete Composite Connections and Beams. Construction and Building Materials, 37, 229-238.

Pratiwi, N \& Tjondro, J. A. (2018). Study on Strength and Stiffness of Meranti Wood Truss with Plywood Gusset Plate Connection and Lag Screw Fastener. Journal of the Civil Engineering Forum, 4(1), 61-66.

Indonesia, S. N. (2013). Spesifikasi desain untuk konstruksi kayu. Jakarta: Badan Standarisasi Nasional, (7973-2013).

Suriani, E., \& Ali Awaludin, S. T. (2012). Perilaku Sambungan Komposit Kayu-beton Dengan Alat Sambung Sekrup Kunci Terhadap Beban Lateral, Indonesia: Doctoral Dissertatio, Universitas Gadjah Mada, Yogyakarta.

Symons, D. D., Persaud, R., \& Stanislaus, H. (2010). Strength of Inclined Screw Shear Connections for Timber and Concrete Composite Construction. The Structural Engineer, 88, 25-32.

Yeoh, D., Fragiacomo, M., De Franceschi, M., \& Heng Boon, K. (2010). State of The Art on TimberConcrete Composite Structures: Literature Review. Journal of Structural Engineering, 137(10), 10851095.

Yeoh, D., Fragiacomo, M., Franceschi, M. D., \& Boon, K. H. (2011). State of the Art on TimberConcrete Composite Structure: Literature Review. Journal of Structural Engineering, 137(10), 10851095.

Yeoh, D., Fragiacomo, M., \& Carradine, D. (2013). Fatigue Behavior of Timber - Concrete Composite Connections and Floor Beams. Engineering Structures, 56, 2240-2248. 